\title{
Nutritional Health Education during Pandemic
}

\author{
Novita Dewi ${ }^{1}$, Wahyu Dini Metrikayanto ${ }^{2}$, Supriyadi $^{3}$ \\ ${ }^{1,2,3}$ Department of Nursing, Tribhuwana Tunggadewi University Malang, Indonesia
}

\begin{tabular}{l} 
Article Information \\
\hline History Article: \\
Received, 04/08/2021 \\
Accepted, 19/10/2021 \\
Published, 05/11/2021
\end{tabular}

\section{Keywords:}

Nutritional intake during the pandemic, Health education in patients

\begin{abstract}
Covid-19 has been booming since December 2019, and is a serious concern in the world. The transmission of this virus is very fast, especially in patients who are hospitalized. So that as a precautionary measure of contracting this virus, actions can be taken in the form of enlightenment in terms of cognitive to the community, in this case in the form of Educational Interactive Communication in the form of Health Education. Health education for patients to meet adequate nutritional intake, so that it is hoped that the spread of this virus can be inhibited with high immunity obtained from varied, balanced nutrition, and all aspects of substances that the body needs can be fulfilled. The purpose of this community service is to provide health education to 15 patients. The method provided is in the form of service learning by providing health education to patients by visiting the patient one by one at each patient. The results of this community service were all participants who understand about nutritional intake, types of balanced nutrition, and things that increase immunity in preventing the transmission of covid-19.
\end{abstract}

(C) 2021 Journal of Community Service for Health

Correspondence Address:

Tribhuwana Tunggadewi University Malang - East Java, Indonesia

E-ISSN : 2746-5195

Email: novita2unitri@gmail.com

DOI: 10.26699/jcsh.v2i2.ART.p042-046

This is an Open Access article under the CC BY-SA license (http://creativecommons.org/licenses/by-sa/4.0/) 


\section{INTRODUCTION}

COVID-19 infection was detected in the city of Wuhan, China in December, and it was the first time in the world. The virus spread throughout the world, in early January the laboratory results identified the Covid-19 virus sequence (Chan, et al.,, 2020; Huang et al., 2020), there were seventy thousand deaths and one million Covid-19 sufferers in March (Ayres, 2020), in Indonesia it was detected in early February. Data from the Task Force for the Acceleration of Handling Covid-19 as of June 24, 2020, 47,896 positive confirmed cases, 2,535 deaths, $5.4 \%$ case fatality rate, $60.6 \%$ male sufferers, and $39.4 \%$ female. Based on this data, men are more likely to die from COVID-19. death due to shortness of breath, usually preceded by fever, dry cough (Hui, D, et al, 2020). Prevention continues to be carried out to reduce and overcome the transmission of the disease, one of which is nutrition to increase basic energy when the virus attacks, by overcoming inflammation, relieving pathogens, to increase body immunity, but if malnutrition results in easy infection (Alwarawrah et al., 2018; Zhang \& Liu, 2020) leading to death due to complications (Aritonang, 2012) otherwise over nutrition obesity which has the potential for many diseases (Alwarawrah, Kiernan, MacIver, 2018), the disease gets worse (Zhang \& Liu, 2020). Adequate nutritional intake is required.

Nutrient intake is the fulfillment of macronutrients and micronutrients. Macronutrients include carbohydrates, proteins and fats, while micronutrients include vitamins and minerals. The nutritional fulfillment of each individual varies depending on several factors; age, development, activity, disease and others. Nutrients can be optimally absorbed in the body, if the amount and variety is right according to the body's needs. WHO has recommended a balanced nutritional menu in the midst of the COVID-19 pandemic, meaning that every food menu must include complete nutrition, both macronutrients and micronutrients. However, to build a strong immune foundation (building block), we must focus on protein intake (UNICEF, 2020) ntake of protein and several other nutritional components will be met according to health standards (Dewi et al., 2020), especially supported by the provision of health education.

Health education is to change behavior related to good health. Health Education is a group that has experienced disease treatment and is susceptible to health problems, especially COVID19. The high number of Covid-19 has the potential to increase infection in patients who are sick, in this case. Based on this phenomenon, it is important for the author to take the title community service of nutrition health education during the Covid-19 pandemic. The aim of community service is to provide health education for nutritional intake during the Covid-19 pandemic to patients.

\section{METHOD}

The methods used in this community service are:

a. Visiting patients one only with their implementation by applying strict health protocol

b. Providing media leaflets containing an explanation of nutritional intake

c. Provision of nutrition intake during a pandemic. Health Education was held on November 24, 2020 The parties involved in community service are Lecturers, professional students department of the basic concepts of nursing 2020/2021

\section{RESULTS}

Community service was carried out on November 24,2020 . The results obtained in this service were in the form of :

Table 1 Frequency distribution of understanding nutritional intake during a pandemic

\begin{tabular}{lll}
\hline variable & $\begin{array}{l}\text { Frequency } \\
(\%)\end{array}$ & $\begin{array}{l}\text { Percent } \\
(\%)\end{array}$ \\
\hline $\begin{array}{l}\text { Nutritional intake } \\
\begin{array}{l}\text { Types of food to maintain } \\
\text { balanced nutrition during } \\
\text { the covid-19 pandemic }\end{array}\end{array}$ & 15 & 100 \\
$\begin{array}{l}\text { Things that can increase } \\
\text { the body's resistance to } \\
\text { prevent the transmission } \\
\text { of covid-19 }\end{array}$ & 15 & 100 \\
\hline Total Souce: Primary Data & 100 \\
\hline
\end{tabular}

Table 1 shows that all patients in 100\% (15 people) were in the category of receiving nutrition during the pandemic. All $100 \%$ of patients (15 people) in the category understand the types of food to maintain balanced nutrition during the covid-19 pandemic. All patients are 100\% (15 people) in the category of understanding things that can increase body resistance to prevent the transmission of covid-19 during a pandemic.

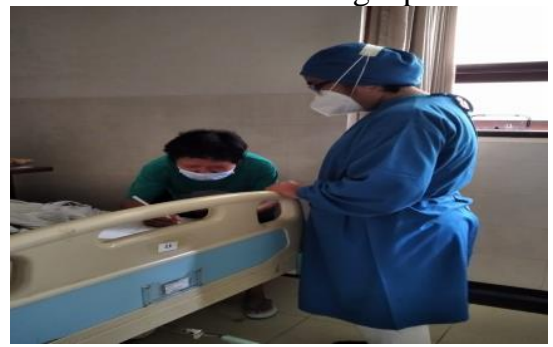



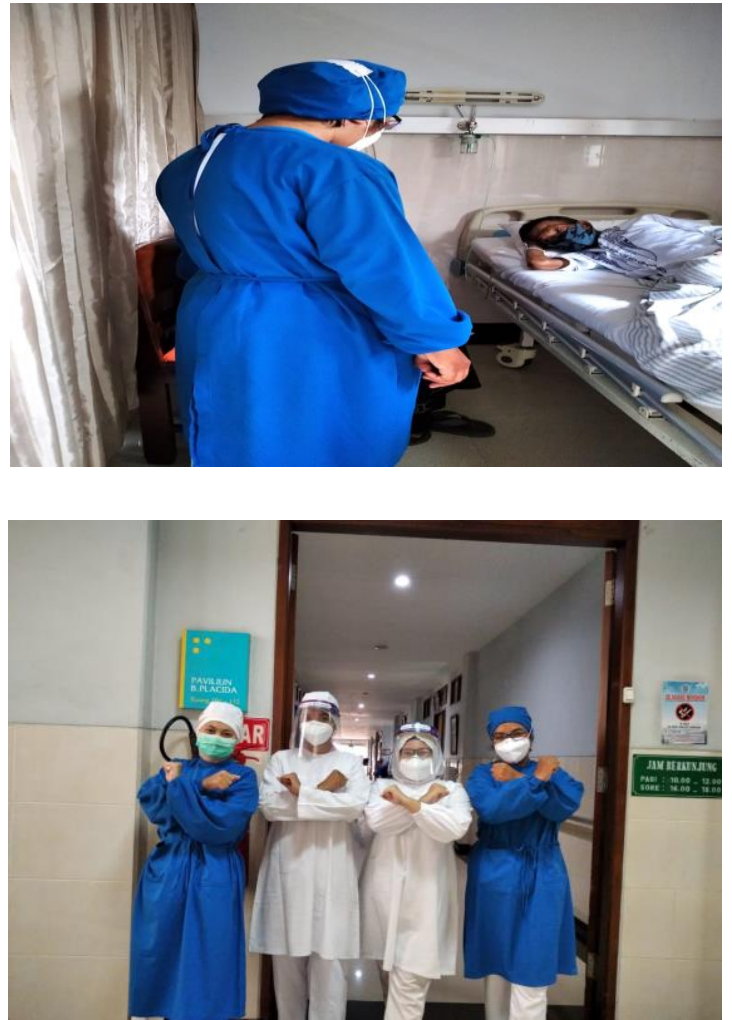

Figure 1 Health education on nutritional intake during a pandemic

1. All health education participants understand about nutritional intake in patients at RSPN Sawahan Malang.

2. All health education participants understand the types of food to maintain balanced nutrition during the covid-19 pandemic

3. All health education participants understand about things that can increase body resistance to prevent the transmission of covid-19

\section{DISCUSSION}

Health education about nutrition during the COVID-19 pandemic for patients and their families has obtained the output of understanding nutrition intake due to the factor of the method of giving health education to patients one by one privately, with coherent explanations, so that patients easily understand nurse explanations, increase respondent knowledge through counseling (Al Hakim et al., 2021; Ardiyani et al., 2021; Besila et al., 2021; Himawan et al., 2021; Nurhana et al., 2021; Sudayasa et al., 2021; Yulianis et al., 2021) directly to the community (Himawan et al., 2021; Lestari \& Lita, 2021). Nurses with this method can see the patient's immediate reaction, for example, when explained the patient shows signs of listening well, in the form of nodding his head, body posture that is ready to receive an explanation, even when lying down, as well as the face covered with a mask, strictly applying the health protocol during pandemic (Fithriyani \& Yesni, 2021; Himawan et al., 2021; Kaidah et al., 2020; Nurhana et al., 2021; Sudayasa et al., 2021; Supriyadi et al., 2021; Wigati et al., 2021). Their seriousness in listening to the nurse's explanation was finally achieved, even though they were sick, they were still able to concentrate well listening, listening, paying attention, so they understood well the material given about nutritional intake during the pandemic.

Another factor that causes maximum understanding of nutritional intake apart from the private method, is the two-way discussion method, in this way, patients can provide feedback on the explanation given, if they don't understand the nurse gives direct explanations, providing opportunities to ask questions. The discussion will eliminate misinformation, lack of knowledge about the information conveyed can be overcome by providing explanations. The discussion provides an opportunity to express what patients understand about their nutritional intake, so it becomes a valid experience that they are currently facing, even though while in hospital food is provided directly by the hospital, but this explanation becomes important when they go home, it is a chat. planning, supplies them while at home.

Another possibility of success is the effectiveness of the time given, in the form of 30 minutes, a very effective time, not too long, so that maximum concentration, focus, and finally the goal of health education is achieved, namely patient understanding of nutritional intake for clients. Effective time is very helpful for patients in understanding the information provided by health workers. If the time is too long, it will certainly be boring, then the information cannot be fully absorbed by the patient properly

Another factor is environmental conditions that support health education. Health education carried out on each patient in a closed room, with curtains attached to each patient bed, is the optimal place to provide a good explanation. The closing of the room while the health center resulted in maximum concentration in paying attention to the nurse's voice, even though she was sick. There is no disturbance of concentration, intermeso with truncated information during health education.

The experience factor is very important in health education. Good communication, coherent explanations, interesting delivery, varied intonations, the language used is according to their knowledge as patients and ordinary people so it is easy to absorb the information provided. Misunderstanding of information causes patients to be confused, often asking questions about their illness, treatment, how to treat the disease, 
supporting examinations, and prevention of the disease they are suffering from.

The media used in the form of leaflets are interesting media, containing information, pictures of various foods that are easy to understand, various pictures of nutritional disorders, making it easier for patients to understand the nurse's explanation about the nutrition included, examples of menus included, combined with traditional information and easy language. understood, has an advantage in composing information about nutrition, various types of macro and micronutrients, how to find out the source of carbohydrates, fats and proteins, so that the roasting of these foods can be easily identified by the patient.

Health education on nutrition during the COVID-19 pandemic for 15 patients and their families was carried out. Health education is carried out by counseling methods to each room using leaflet media. The implementation of health education is carried out within 30 minutes, with 15 minutes of exposure to health information about nutrition during the COVID-19 pandemic and followed by 15 minutes for discussion.

Health education materials delivered by 2 presenters include:

1. Definition of nutrition

2. Nutritional function

3. Types of food to maintain balanced nutrition during the COVID-19 pandemic

4. Things that can increase the body's resistance to prevent the transmission of COVID 19

Based on the exposure given during health education and the number of questions given by the patient and the patient's family, it shows that the patient and family are quite enthusiastic in participating in health education activities. Various questions were given, many were asked about how nutrition should be consumed during the COVID-19 pandemic, besides that the patient's family also asked a lot of questions about how balanced nutrition should be consumed. Another question that is often asked by the patient's family is about how prevention can be done by the family and patient to avoid COVID-19 disease.

This health education is considered effective by the service because the many questions given by patients and their families during the COVID19 pandemic can add insight. All questions asked have been answered and can provide additional information for patients and their families. Active participants ask questions as long as they are given the opportunity to ask questions, they nod their heads when given an explanation/explanation of the health education that has been given. The patient is able to answer the questions that have been given, although not exactly as described, then the presenter provides answers that are complementary to the researcher's questions.

At the end of the session, an evaluation was carried out in which the presenters asked questions from the material that had been presented and discussed. Most of the patient's family can answer questions simultaneously and in detail. The patient and family also said that they were happy with the counseling activities on nutrition during the pandemic and hoped that the presenters could provide more information about other materials about patient nutrition according to their illness at a later time. Based on the answers given, it shows that the patient and family can understand what the speaker has given.

\section{CONCLUSIONS}

Conclusions in community service that have been carried out on patients are obtained. All participants understand about nutritional intake during the pandemic. All patients understand the types of balanced nutritional intake during a pandemic. All public health education audiences understand things that can increase immunity in order to prevent contracting cocid-19.

\section{SUGGESTIONS}

The next community service uses interactive media, video shows, demonstrations and simulations of material selection so that the information given can be understood even though the patient is sick.

\section{REFERENCES}

Al Hakim, L., Supeni, S., Khabibullah, M., \& Skenoma, Y. (2021). Pemberdayaan Masyarakat Desa Plesungan Melalui Penyuluhan Pembuatan Oleh-Oleh Makanan dan Cenderamata Khas Desa. Jurnal Abdimas PHB: Jurnal Pengabdian Masyarakat Progresif Humanis Brainstorming, 4(1), 53-61.

Alwarawrah, Y., Kiernan, K., \& MacIver, N. J. (2018). Changes in nutritional status impact immune cell metabolism and function. Frontiers in Immunology, 9(MAY), 1-14. https://doi.org/10.3389/fimmu.2018.01055

Ardiyani, V. M., Dewi, N., \& Supriyadi, S. (2021). Penyuluhan Terapi Komplementer Rimpang Dan Rempah Indonesia Sebagai Penguat Imunitas Tubuh Di Masa Pendemi Di Masyarakat Tlogomas Malang. Jurnal Pengabdian Kepada Maysrakat: Kesehatan, 1(1).

Aritonang, E. S. (2012). Pola Konsumsi Pangan, Hubungan Dengan Status Gizi Dan Prestasi 
Belajar Pada Pelajar SD Di Daerah Endemik GAKI Desa Kuta Dae Kecamatan Kerajaan Dairi Propinsi Sumatra Utara. Universitas Sumatra Utara.

Ayres, J. S. (2020). Surviving COVID-19: A disease tolerance perspective. Science Advances.

Besila, Q. A. B. A., Mangunsong, N. I., \& Debora, T. P. (2021). Penyuluhan Pemanfaatan Lahan Terbatas Untuk Menunjang Ketahanan Pangan Keluarga Selama Masa Pandemi Covid 19. Jurnal AKAL: Abdimas Dan Kearifan Lokal, 2(1).

Chan, J. F.-W., Yuan, S., kok, K.-H., To, K. K.-W., Chu, h., Yang, j.Yuen, K.-Y. . (2020). A familial cluster of pneumonia associated with the 2019 novel coronavirus indicating person-to-person transmission: a study of a family cluster. Lancet, 514-523.

Dewi, N., Maemunah, N., \& Putri, R. M. (2020). Gambaran Asupan Nutrisi Dimasa Pandemi Pada Mahasiswa. Care: Jurnal Ilmiah Ilmu Kesehatan, 8(3), 369-382.

Fithriyani, F., \& Yesni, M. (2021). Edukasi tentang Protokol Pencegahan Covid-19 kepada Masyarakat Kelurahan Lebak Bandung Kota Jambi. Jurnal Abdimas Kesehatan (JAK), 3(2), 174-177.

Himawan, F., Suparjo, S., \& Hudinoto, H. (2021). Edukasi Dan Sosialisasi Pencegahan Covid19 Melalui Upaya Peningkatan Imunitas Tubuh Dengan Dzikir Dan Herbal Di Kelurahan Debong Kulon Tegal. JABI: Jurnal Abdimas Bhakti Indonesia, 2(1), 4350.

Kaidah, S., Budiarti, L. Y., Yasmina, A., \& Heriyani, F. (2020). Edukasi Penggunaan Masker dan Handsanitizer Bagi Petugas Kebersihan di Fakultas Kedokteran ULM. Prosiding Konferensi Nasional Pengabdian Kepada Masyarakat Dan Corporate Social Responsibility (PKM-CSR), 3, 299-306.

Lestari, R. F., \& Lita, L. (2021). Protokol Keluar dan Masuk Rumah Selama Pandemi Covid19. Jurnal Abdimas Kesehatan (JAK), 3(2), 131-135.

Nurhana, S., Safitri, U. R., \& Setiawati, D. (2021). Edukasi Penerapan Protokol Kesehatan Di Tpa An-Nur, Dukuh Gading, Ngargosari, Ampel, Boyolali. Jurnal Ekonomi, Sosial \& Humaniora, 2(09), 81-85.

Sudayasa, I. P., Haryati, H., Purnamasari, Y., Chintia, Y. F., Anwar, N. R., Permatasari, P., \& Pebriyanti, P. (2021). Peningkatan Pengetahuan Masyarakat dalam Penerapan Protokol Kesehatan melalui Edukasi Berbasis Media Online. PengabdianMu: Jurnal Ilmiah Pengabdian Kepada Masyarakat, 6(2), 175-183.

Supriyadi, S., Ardiyani, V. M., \& Dewi, N. (2021).
Gambaran Pelaksanaan Social Distancing dan Protokol Kesehatan dimasa Pandemi Covid-19 pada Mahasiswa. Wiraraja Medika: Jurnal Kesehatan, 11(1), 20-24.

UNICEF. (2020). Supporting children's nutrition during the COVID-19 pandemic UNICEF and WFP are scaling up efforts to prevent and treat child wasting in response to the impact of COVID-19. 2.

Wigati, D., Lindawati, S., Anggitasari, W., \& Purwanti, A. (2021). Edukasi Penerapan Protokol Kesehatan pada Remaja di Pondok Pesantren "SHOFA MARWA" Pakusari, Jember. Jurnal Dimas, 3(1), 103-106.

Wu, C., Chen, X., Cai, Y., Xia, J., Zhou, X., Xu, S., Huang, H., Zhang, L., Zhou, X., Du, C., Zhang, Y., Song, J., Wang, S., Chao, Y., Yang, Z., Xu, J., Zhou, X., Chen, D., Xiong, W., ... Song, Y. (2020). Risk Factors Associated with Acute Respiratory Distress Syndrome and Death in Patients with Coronavirus Disease 2019 Pneumonia in Wuhan, China. JAMA Internal Medicine, $180(7)$, 934-943. https://doi.org/10.1001/jamainternmed.2020. 0994

Yulianis, Y., Wardana, A. K., Wati, D., Dila, I., Della F, N., Rosmawati, R., Suryani, S., Oktaviani, W., \& Hidayah, N. (2021). Penyuluhan tentang cara menjaga kesehatan di masa pandemi di Kelurahan Pakuan Baru Jambi. Jurnal Pengabdian Harapan Ibu (JPHI), 3(1), 39-46.

Zhang, L., \& Liu, Y. (2020). Potential interventions for novel coronavirus in China: A systematic review. Journal of Medical Virology, 92(5), 479-490. https://doi.org/10.1002/jmv.25707 